\title{
Molecular Cloning and Purification of Klebicin B
}

\author{
By RICHARD JAMES \\ Molecular Biology Group, School of Biological Sciences, University of East Anglia, \\ Norwich NR4 7TJ, Norfolk, UK
}

(Received 21 December 1987; revised 1 June 1988)

\begin{abstract}
A novel klebicin, klebicin B, produced by an isolate of Klebsiella pneumoniae has been identified. It is encoded by a $5.5 \mathrm{~kb}$ plasmid, pKlebB-K $17 / 80$, which is mobilized into $K$. pneumoniae UNF 5023 by a large plasmid found in the same strain. The $5.5 \mathrm{~kb}$ plasmid has been cloned into the high-copy-number vector pUC19 and the restriction map of the resulting recombinant plasmid pRJ180 has been determined. Using sub-cloning and transposon mutagenesis, the klebicin B structural gene, the klebicin B immunity gene and the mitomycin C (MC) sensitivity gene $(l y s)$ present on $\mathrm{pRJ} 180$ have been localized. Transposon inserts which inactivated klebicin production also abolished lysis protein production encoded by pRJ180, but did not affect klebicin B immunity. Using SDS-PAGE an MC-induced polypeptide of $85 \mathrm{kDa}$ was observed in cultures of $K$. pneumoniae UNF5023(pRJ180). This polypeptide was absent in cultures carrying plasmid pRJ180 with a Tn 1000 insert which inactivated klebicin production. Analysis of the polypeptides present in the medium of Escherichia coli JM83 hsdR(pRJ180) or K. pneumoniae UNF5023(pRJ180) indicated that the $85 \mathrm{kDa}$ polypeptide is specifically secreted from the producing cell. Klebicin $\mathrm{B}$ has been purified, using gel filtration, from a cell-free extract of $K$. pneumoniae UNF5023(pRJ180) which had been induced with MC. After boiling in sample buffer the purified klebicin B gave rise to two peptides on SDS-PAGE, one of $85 \mathrm{kDa}$ and the other of $11 \mathrm{kDa}$. Klebicin B-resistant mutants of $K$. pneumoniae UNF5023 were sensitive to klebicin A, colicin B and colicin D.
\end{abstract}

\section{INTRODUCTION}

Klebsiella species are common causes of hospital-acquired infections of the lower respiratory tract, urinary tract, surgical wounds and blood (Cross et al., 1983). The mortality rates reported for Klebsiella bacteraemia and pneumonia range from $25 \%$ to $50 \%$ (Cryz et al., 1986). These serious consequences of infection by Klebsiella indicate the need for detailed epidemiological analysis of such hospital-acquired infections, but this is limited by the absence of suitable typing schemes. At present the only feasible methods involve capsular serotyping, which involves 77 different antisera (Ørskov \& Ørskov, 1984), bacteriophage typing (Gaston et al., 1987) and klebicin (bacteriocin) typing.

Bacteriocins are plasmid-encoded, protein antibiotics which are produced by a wide variety of bacterial species. The most extensively studied bacteriocins are the colicins, produced by strains of Escherichia coli. The colicins are classified into groups based upon their target receptor on the sensitive cell, e.g. the $\mathrm{E}$ group colicins all use the $b t u B$ gene product of $E$. coli as a receptor on the cell surface of sensitive cells. E colicin plasmids also encode an immunity protein which protects the producing cell from the lethal effect of the colicin. In most of the $\mathrm{E}$ colicins which have been studied, the immunity protein forms a complex with the colicin soon after synthesis (Pugsley \& Oudega, 1987). E. coli K12 strains carrying ColE plasmids are also sensitive to mitomycin C (MC) compared to plasmid-free isogenic strains (Herschman \& Helinski, 1967). This is the

Abbreviations: Xgal, 5-bromo-4-chloro-3-indolyl $\beta$-D-galactopyranoside; MC, mitomycin C. 
result of induction by $\mathrm{MC}$ of a third plasmid-coded lysis gene which is involved in the release of the colicin/immunity protein complex from the producing cell (Shafferman et al., 1979; Pugsley \& Schwartz, 1983; Suit et al., 1983; Chak \& James, 1984).

Several klebicin typing schemes have been proposed for the epidemiological investigation of Klebsiella infections (Slopek \& Maresz-Babczyszyn, 1967; Hall, 1971; Buffenmeyer et al., 1976; Heddel \& Mitchell, 1978; Edmondson \& Cooke, 1979; Bauernfeind et al., 1981; Israil, 1981), but none has received universal acceptance. Each scheme involves testing isolates for resistance or sensitivity to the bacteriocins (klebicins) produced by a set of producer strains. The choice of producer strains, different in most of the schemes, is empirical, and in some schemes MC is used to increase the titre of the klebicin. The klebicins used are uncharacterized as regards their number, titre and type, whilst the interpretation of the results is subjective, especially the 'weak sensitive' response. The use of stable, high-titre preparations of receptor-specific klebicins will markedly increase the reliability and therefore the applicability of klebicin typing in clinical microbiology (Cooper \& James, 1985; James et al., 1987). In continuation of the attempt to develop a panel of high-titre, receptor-specific klebicins, here the identification, characterization and molecular cloning of klebicin $B$ is described.

\section{METHODS}

Bacterial strains and plasmids. The strains of Klebsiella pneumoniae and Escherichia coli used in this work are listed in Table 1; the derivation of recombinant plasmids is shown in Table 2.

Media. Bacteria were cultured at $37^{\circ} \mathrm{C}$ in L broth (Miller, 1972). The chromogenic substrate Xgal was included in $\mathrm{L}$ agar ( $\mathrm{L}$ broth containing $1.5 \%$, w/v, agar) at a final concentration of $20 \mu \mathrm{g} \mathrm{ml}^{-1}$ to detect recombinant plasmids. Ampicillin was included in all media, at a final concentration of $100 \mu \mathrm{g} \mathrm{ml}^{-1}$ for the growth of all E. coli $\mathrm{K} 12$ strains which carried recombinant plasmids, and at a final concentration of $200 \mu \mathrm{g} \mathrm{ml}^{-1}$ for all $K$. pneumoniae strains which carried recombinant plasmids.

Klebicin production and immunity tests. Klebicin production was determined by stab tests (Ozeki et al., 1962), using K. pneumoniae UNF5023 as the sensitive indicator strain. Klebicin immunity was determined by overlaying stabs of klebicin-producing strains with lawns of $K$. pneumoniae UNF5023 carrying the test plasmid. Each test was performed on at least six isolates from each test culture to determine the phenotype conferred by each recombinant plasmid.

Plasmid isolation, restriction, ligation, transformation and electrophoresis. All plasmids were prepared by the method of Birnboim \& Doly (1979). The methods for restriction, ligation, transformation and electrophoresis of plasmid DNA have been previously described (Chak \& James, 1984). Phosphorylated linkers (Pharmacia) were inserted into plasmids using the method of Maniatis et al (1982).

Conjugation. Conjugation between klebicinogenic donors and $K$. pneumoniae UNF5023 was done as previously described (Cooper \& James, 1985).

Transposon mutagenesis. Transposon mutagenesis with Tn1000 was done as previously described (Chak \& James, 1984). The insertion sites of Tn 1000 were determined by restriction with EcoRI, BamHI and HindIII (Guyer, 1978).

Electrophoresis of klebicins. Cultures of $K$. pneumoniae UNF5023 carrying appropriate plasmids were grown in L broth to an $\mathrm{OD}_{550}$ of 0.2 before the addition of $\mathrm{MC}\left(0.5 \mu \mathrm{g} \mathrm{ml}^{-1}\right)$ to half of each culture to induce the synthesis of klebicins. After $2 \mathrm{~h}$ further incubation, $1.5 \mathrm{ml}$ of each culture was removed and the cells were recovered by centrifugation. The cell pellet was resuspended in $100 \mu \mathrm{l}$ electrophoresis sample buffer, heated to $100{ }^{\circ} \mathrm{C}$ for $5 \mathrm{~min}$ and then centrifuged again. Samples $(25 \mu \mathrm{l})$ of the total cell proteins were then analysed by SDS-PAGE (Laemmli, $1970)$ in $10 \%(\mathrm{w} / \mathrm{v})$ gels using standard proteins as molecular mass markers. The supernate from the $1.5 \mathrm{ml}$ culture was used to prepare samples of extracellular proteins by the method described in Pugsley \& Oudega (1987). This experiment was repeated twice with identical results.

Purification of klebicin B. Klebicin B was purified from a 1 litre culture of $K$. pneumoniae UNF5023(pRJ180) after induction with MC for $2 \mathrm{~h}$. The culture was then centrifuged at $10000 \mathrm{~g}$ for $15 \mathrm{~min}$ and the supernate recovered. Solid ammonium sulphate was added slowly, with stirring, to a final concentration of $60 \%$ saturation and the supernate was then left at $4{ }^{\circ} \mathrm{C}$ for $30 \mathrm{~min}$. The precipitated proteins were recovered by centrifugation at $10000 \mathrm{~g}$ for $15 \mathrm{~min}$ and resuspended in $50 \mathrm{ml} 50 \mathrm{mM}$-phosphate buffer, $\mathrm{pH} 7 \cdot 0$, before dialysis against 5 litres of the same buffer for $16 \mathrm{~h}$. The retentate was then titrated on soft agar lawns of UNF5023 and analysed by gel filtration on a Superose 6 column using an FPLC system (LKB). Column fractions were concentrated by precipitation with 2 vols $100 \%$ ethanol at $4{ }^{\circ} \mathrm{C}$ and were resuspended in $50 \mathrm{~mm}$-phosphate buffer, pH 7.0. 
Table 1. Bacterial strains

\begin{tabular}{|c|c|c|}
\hline Strain & Relevant properties & Source or derivation \\
\hline \multicolumn{3}{|c|}{ K. pneumoniae } \\
\hline K $17 / 80$ & Prototrophic strain & P. Mortimer (PHLS, Colindale) \\
\hline UNF5023 & his hsdR rpsL & M. Merrick (University of Sussex) \\
\hline РC902 & UNF5023(pCloDF13) & Cooper \& James (1985) \\
\hline PC905 & UNF5023(pP5a) & Cooper \& James (1985) \\
\hline PC909 & UNF5023(pP5b) & Cooper \& James (1985) \\
\hline PC910 & UNF5023(R64-11)(pP3) & Cooper \& James (1985) \\
\hline RJ102 & UNF5023 CloDF13 & This paper \\
\hline RJ105 & UNF5023 KlebB ${ }^{R}$ & This paper \\
\hline \multicolumn{3}{|l|}{ E. coli } \\
\hline W3110 & Prototrophic strain & Pugsley \& Oudega (1987) \\
\hline JM83 hsdR & 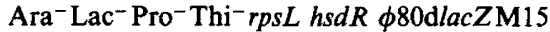 & This laboratory \\
\hline RJ103 & W3110(pColB $)$ & Pugsiey \& Oudega (1987) \\
\hline RJ104 & W3110(pColD) & Pugsley \& Oudega (1987) \\
\hline RJ106 & JM83 hsdR(pUC18) & Vieira \& Messing (1982) \\
\hline RJ107 & JM83 hsdR(pUC19) & Vieira \& Messing (1982) \\
\hline
\end{tabular}

\section{Table 2. Derivation of recombinant plasmids}

Plasmid

pRJ180 pRJ271 PRJ72 pRJ277 pRJ278 pRJ279 pRJ281 pRJ282 pRJ283 pRJ284 pRJ285 pRJ286

\section{Derivation}

The whole pKlebB-K $17 / 80$ plasmid cloned into the HindIII site of pUC19

The $4.5 \mathrm{~kb}$ HindIII-SalI fragment of pKlebB-K17/80 cloned into the Sall-HindIII site of pUC18 The $1.0 \mathrm{~kb}$ Pstl fragment of pRJ271 deleted

The $4.5 \mathrm{~kb}$ HindIII-Sall fragment of pKlebB-K17/80 cloned into the HindIII-Sall site of pUC19 The $2.8 \mathrm{~kb}$ BamHI-SaII fragment of pRJ 277 deleted The $1.05 \mathrm{~kb}$ SacI-BamHI fragment of pRJ278 deleted Insertion of an EcoRI linker into the EcoRV site of pRJ279 Insertion of an HindIII linker into the EcoRV site of pRJ279 Deletion of the $0.65 \mathrm{~kb} E c o$ RI fragment of pRJ281

Deletion of the $1.05 \mathrm{~kb}$ HindIII fragment of pRJ 282

Insertion of an HindIII linker into the EcoRV site of pRJ 277

Deletion of the $1.05 \mathrm{~kb}$ HindIII fragment of pRJ285

\section{RESULTS AND DISCUSSION}

\section{Identification of 'novel' klebicins}

In an attempt to identify strains producing 'novel' klebicins, strains from klebicin-producing panels described by others and from collections of clinical isolates were screened. Strains which produced a zone of inhibition against $K$. pneumoniae UNF5023 were then tested as producers against $K$. pneumoniae RJ102. This mutant strain was isolated as a spontaneous cloacin DF13resistant mutant of UNF5023. It is also resistant to klebicins A1, A2 and A3, and is therefore a presumptive receptor mutant for the group A klebicins. Strains which produced a zone of inhibition against RJ 102 were then tested as indicators against $E$. coli strains producing colicin B and colicin D, colicins which are also active against Klebsiella (P. C. Cooper, personal communication). Strains which were sensitive to these two colicins were then classed as presumptive 'novel' klebicin-producing strains and were subjected to further analysis. One such strain was K17/80 from a collection of Klebsiella clinical isolates collected by P. Mortimer, Coventry, UK. The klebicin produced by this strain was tentatively assigned to the group B klebicins.

\section{Characterization of the klebicin-encoding plasmid of K17/80}

Electrophoresis of plasmid DNA prepared from $K$. pneumoniae $\mathrm{K} 17 / 80$ revealed the presence of a large plasmid of $>80 \mathrm{~kb}$ and a smaller plasmid of $5.5 \mathrm{~kb}$ (data not shown). Using a partially purified, cell-free extract prepared from MC-induced cultures of $\mathrm{K} 17 / 80$ as a selection agent, K17/80 was conjugated with UNF5023. Klebicin B-immune, streptomycin-resistant transconju- 


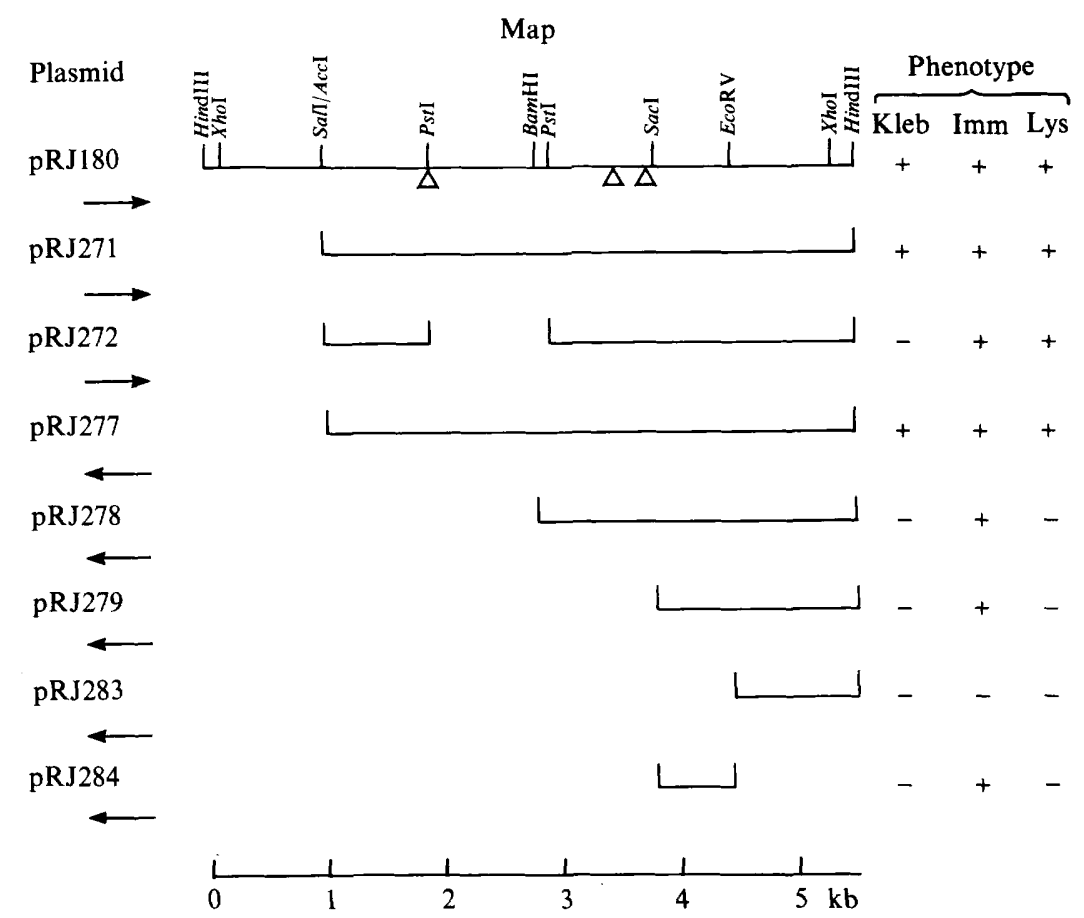

Fig. 1. Restriction map and subclones of pKlebB-K17/80. The restriction fragments present in the plasmids listed are indicated (for clarity the vector sequences are not shown), together with the phenotypes conferred. The arrows indicate the direction of transcription through the insert fragment initiated from the vector $l a c$ promoter. Tn 1000 insertion sites which inactivate the klebicin B gene of $\mathrm{pRJ} 180$ are indicated by triangles on the restriction map.

gants were screened for the production of klebicin B. All of the transconjugant colonies which produced klebicin contained both the large and the small plasmid, suggesting that the small plasmid may encode klebicin B. It appears that the large plasmid present in K17/80 is capable of mobilizing the small klebicin-encoding plasmid. A plasmid preparation from $\mathrm{K} 17 / 80$ was used to transform UNF5023 to klebicin B immunity. All colonies which produced klebicin B contained the $5.5 \mathrm{~kb}$ plasmid. This plasmid was designated as pKlebB-K17/80.

\section{Restriction mapping of plasmid pKlebB-K17/80}

Restriction of the $5.5 \mathrm{~kb}$ plasmid pKlebB-K 17/80 with BamHI, HindIII, or Sall yielded single fragments of $5.5 \mathrm{~kb}$ which were ligated into pUC19 restricted with the appropriate enzyme. After transformation of $E$. coli JM83 $h s d R$, clones carrying recombinant plasmids were then screened for klebicin B production. A recombinant plasmid, $\mathrm{pRJ} 180$, which encoded klebicin $B$ was obtained from the HindIII clones. Restriction of pRJ180 with HindIII confirmed the presence of the $2.7 \mathrm{~kb}$ vector fragment and a $5.5 \mathrm{~kb}$ insert fragment derived from pKlebBK17/80. Using pRJ180 a restriction map of the pKlebB-K17/80 plasmid was obtained (Fig. 1). Colonies of UNF5023(pRJ180) expressed klebicin B production, klebicin B immunity and lysis protein production (Fig. 2). Klebicin B immunity was tested using stabs of PC909 and UNF5023(pRJ180). All klebicin B-immune strains were still sensitive to the klebicin A2 produced by PC909. Also the MC sensitivity encoded by pRJ180 was expressed in $E$. coli JM83 hsdR (data not shown).

\section{Transposon mutagenesis of pRJ180}

In an attempt to localize the klebicin, immunity protein and lysis genes present on pRJ180 and to investigate their genetic organization, transposon mutagenesis with $\mathrm{Tn} 1000$ was performed. Tn 1000 inserts which mapped at $1.9 \mathrm{~kb}, 3.5 \mathrm{~kb}$ and $3.7 \mathrm{~kb}$ from the left-hand 


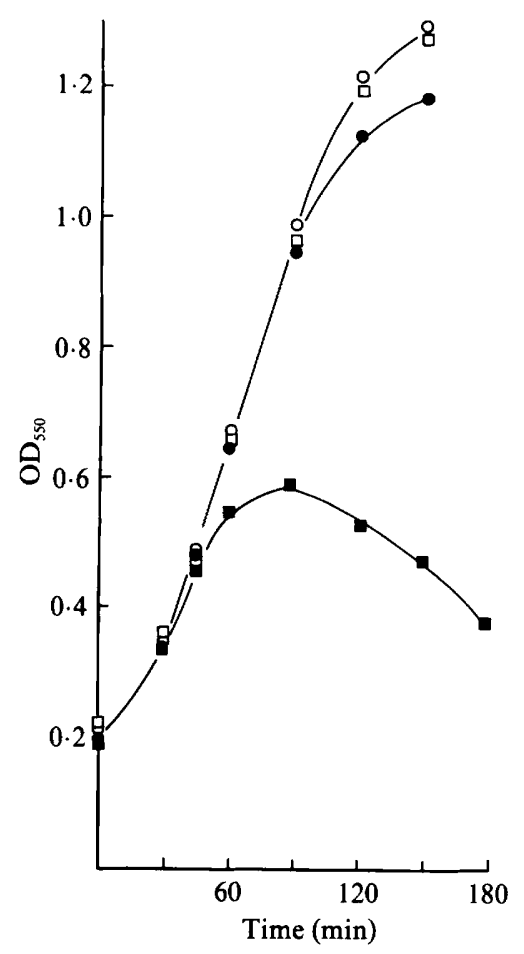

Fig. 2. MC-inducible cell lysis conferred by pRJ 180 . Cultures of $K$. pneumoniae UNF5023 carrying pUC19 $(O, \square)$ or pRJ180 (O, $\square$ ) were grown in L broth containing ampicillin. At time zero, MC $\left(0.5 \mu \mathrm{g} \mathrm{ml}^{-1}\right)$ was added to half of each culture, as indicated by the square symbols. This experiment was repeated three times, and in each case the results were comparable to those shown.

HindIII site of pRJ180 inactivated klebicin B production (Fig. 1) and lysis, but did not affect klebicin B immunity. In many other bacteriocinogenic plasmids cell lysis is dependent upon transcription from the DNA-damage inducible promoter located proximal to the 5 ' end of the bacteriocin structural gene, and is abolished by transposon inserts which inactivate the bacteriocin structural gene (Chak \& James, 1986). Bacteriocin immunity protein genes often have their own promoters which are independent of the promoter of the bacteriocin structural gene (Chak \& James, 1985, 1986). Our results with the klebicin B recombinant plasmid pRJ180 are consistent with this functional organization.

\section{Sub-cloning of pRJ 180}

Deletion of the $1 \mathrm{~kb}$ HindIII-SalI fragment of pRJ180, yielding pRJ271, had no effect upon klebicin production, immunity or lysis protein production. This localizes the klebicin $B$ structural gene, the klebicin B immunity gene and the lysis gene to the $4.5 \mathrm{~kb}$ SalI-HindIII fragment of pKlebB-K17/80 (Fig. 1). Deletion of the $1 \cdot 1 \mathrm{~kb}$ PstI fragment of pRJ271, yielding pRJ272, abolished klebicin production but did not affect klebicin B immunity, or lysis. This localizes at least part of the klebicin B structural gene, but not its promoter, to this PstI fragment, a result which is consistent with the transposon mutagenesis data. Deletion of the $2.8 \mathrm{~kb}$ BamHI-SalI fragment of pRJ277, resulting in pRJ278, abolished klebicin production and cell lysis, but did not affect klebicin immunity. Further deletion of the $1.05 \mathrm{~kb} \mathrm{SacI-BamHI}$ fragment of pRJ278 yielded pRJ279, which still conferred klebicin immunity. In order to further localize the klebicin immunity gene we inserted linkers which contain a restriction site for $E c o$ RI or HindIII into the blunt-ended EcoRV site of pRJ279. The resulting plasmids, pRJ281 and pRJ282 respectively, were then restricted with EcoRI or HindIII in order to delete the $650 \mathrm{bp} E c o \mathrm{RV}-S a c I$ fragment, or the $1.05 \mathrm{~kb}$ HindIII-EcoRV fragment, respectively. The phenotypes conferred by the resulting plasmids pRJ283 and pRJ284 (Fig. 1) conclusively localized the klebicin B immunity gene to the $650 \mathrm{bp}$ SacI-EcoRV fragment of pRJ 180. 
The lys gene of pRJ180 was localized after insertion of HindIII linker into the EcoRV site of pRJ277. The resulting plasmid, pRJ285, was then restricted with HindIII to delete the $1.05 \mathrm{~kb}$ EcoRV-HindIII fragment. The resulting recombinant plasmid, pRJ286, conferred klebicin production and immunity but not lysis (data not shown). This localized the lys gene to the $1.05 \mathrm{~kb} E c o \mathrm{RV}-$ HindIII fragment of pRJ180 and is consistent with our findings that this fragment can only be cloned downstream of the strong lac promoter, present in pUC vectors, in the orientation found in $\mathrm{pRJ} 283$. This strongly suggests that the direction of transcription of the lys gene is from left to right in Fig. 1. This orientation of transcription is also consistent with our

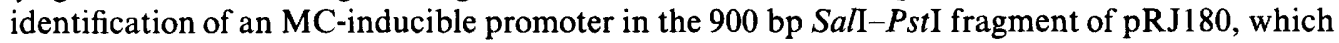
also transcribes from left to right (data not shown). The genetic organization of the klebicin $B$ operon is thus similar to that of most E colicin plasmids, with the bacteriocin gene and the lys gene being transcribed in the same orientation from the SOS promoter localized proximal to the $5^{\prime}$ end of the bacteriocin gene. The immunity gene is localized between the klebicin gene and the lys gene and probably has its own promoter.

\section{Purification of klebicin B}

SDS-PAGE of total cell proteins of $K$. pneumoniae UNF5023 carrying pRJ180 demonstrated the presence of an MC-inducible protein of $85 \mathrm{kDa}$. This protein was identified as klebicin $\mathrm{B}$ on the basis that $\operatorname{Tn} 1000$ inserts in pRJ180, which inactivated the klebicin B gene, resulted in the absence of this band (Fig. $3 a$ ). A protein of this size would require a coding capacity of $2.3 \mathrm{~kb}$, which indicates that the $\mathrm{Tn} 1000$ inserts in $\mathrm{pRJ} 180$ which inactivate klebicin B production delimit some $80 \%$ of the gene (Fig. 1). No low-molecular-mass polypeptide corresponding to the immunity protein was clearly visible in these gels. Analysis of the proteins in the medium of MCinduced cultures of $E$. coli JM83 $h s d R(\mathrm{pRJ} 180)$ or $K$. pneumoniae UNF5023(pRJ180) indicated that the klebicin is specifically secreted from the producing cell (Fig. $3 b$ ). This observation was used as the first stage of a protein purification procedure for klebicin B. Gel filtration of the partially purified klebicin $B$ revealed the presence of two major protein peaks (data not shown). The first had an apparent molecular mass of $87 \mathrm{kDa}$ and, unlike the second peak, contained active klebicin B. On SDS-PAGE the $87 \mathrm{kDa}$ peak gave rise to two bands of $85 \mathrm{kDa}$ and $11 \mathrm{kDa}$, which suggested that klebicin $\mathrm{B}$, like other bacteriocins, is secreted as a complex of the klebicin and its associated immunity protein. Klebicin B is the largest bacteriocin to be reported with the exception of colicin D (Pugsley \& Oudega, 1987).

\section{Klebicin B-resistant mutants}

A purified klebicin B preparation was used to select klebicin B-resistant mutants of UNF5023. Twelve klebicin B-resistant mutant colonies were then grown up in LB and tested as indicators against stabs of PC902, PC909, PC910, RJ103, RJ104 and UNF5023(pRJ180). In all twelve the results obtained were identical to those shown in Table 3 for the representative mutant strain RJ105. Klebicin B-resistant mutants of UNF5023 are sensitive to all klebicin A producers as well as to colicin B and colicin D. By analogy with other bacteriocin-resistant mutants selected in this way, it is probable that the klebicin B-resistant mutants of UNF5023 which were selected are receptor mutants. The mutant strain RJ105 is therefore a specific indicator strain for klebicin B producers.

\section{Evolutionary relationships between bacteriocins}

Detailed characterization of the cloacin DF13 and the colicin E3 operons has indicated sequence homology between the $\mathrm{C}$-terminal killing activity fragments of these two bacteriocins, although the $\mathrm{N}$-terminal receptor binding fragments are very different (Mock et al., 1983). A further relationship between pCloDF13 and the ColE plasmids is indicated by the observation that pCloDF13 confers colicin E6 immunity (Males \& Stocker, 1982). Two other members of the group A klebicin plasmids, to which pCloDF13 also belongs, confer colicin E3 immunity. Using subcloning and transposon mutagenesis, it has been shown that in one case the colicin E3 immunity and the klebicin immunity are determined by the same gene, whilst in the other they are determined by separate genes (James et al., 1987). These examples of relationships are 

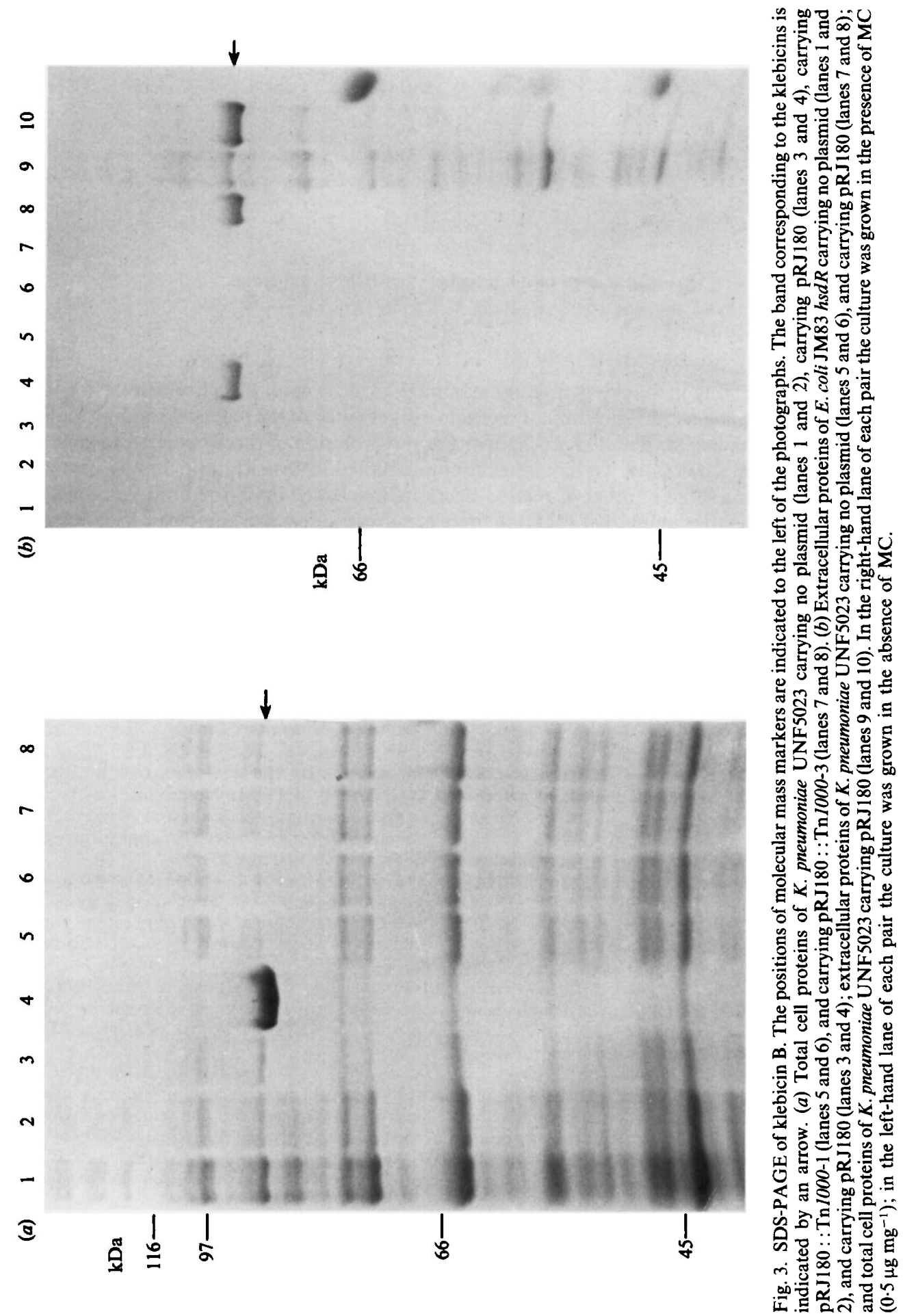
Table 3. Sensitivity and resistance of RJ105 to bacteriocins

The plasmid present in the indicator strain is given in parentheses.

\begin{tabular}{|c|c|c|c|c|c|c|}
\hline \multirow[b]{2}{*}{ Indicator strain } & \multicolumn{6}{|c|}{ Reaction to bacteriocin* } \\
\hline & $\begin{array}{l}\text { Cloacin } \\
\text { DF13 }\end{array}$ & $\begin{array}{l}\text { Klebicin } \\
\quad \text { A2 }\end{array}$ & $\begin{array}{c}\text { Klebicin } \\
\text { A3 }\end{array}$ & $\underset{\text { B }}{\text { Colicin }}$ & $\begin{array}{c}\text { Colicin } \\
\text { D }\end{array}$ & $\begin{array}{c}\text { Klebicin } \\
\text { B }\end{array}$ \\
\hline UNF5023 & + & + & + & + & + & + \\
\hline UNF5023(pCloDF13) & - & + & + & + & + & + \\
\hline UNF5023(pP5b) & + & - & + & + & + & + \\
\hline UNF5023(pP3) & + & + & - & + & + & + \\
\hline RJ102 & - & - & - & + & + & + \\
\hline RJ105 & + & + & + & + & + & - \\
\hline
\end{tabular}

particularly interesting in that klebicins, or cloacin DF13, do not kill E. coli, whilst the E colicins do not kill $K$. pneumoniae; this presumably reflects a divergence in the receptor-binding region of the klebicins/colicins. The detailed mechanisms of the evolution of these bacteriocin genes can only be speculated upon until we have much more detailed information, including nucleotide sequence data, on a large number of related bacteriocins. Based upon the limited information provided by the restriction map of $\mathrm{pRJ} 180$, there is no restriction site homology with any other bacteriocin operon which has been characterized. The identification and characterization of 'novel' klebicins may therefore be of value in these basic studies as well as for our aim of developing a rational klebicin typing scheme.

This research was funded by a generous grant from the Wellcome Trust. I am grateful to Pearl C. Cooper for extensive discussions of this work and to Jill Debbage and Lynne James for excellent technical assistance.

\section{REFERENCES}

Bauernfeind, A., Petermuller, C. \& Schneider, R. (1981). Bacteriocins as tools in analysis of nosocomial Klebsiella pneumoniae infections. Journal of Clinical Microbiology 14, 15-19.

Birnborm, H. C. \& Doly, J. (1979). A rapid alkaline extraction procedure for screening plasmid DNA. Nucleic Acids Research 7, 1513-1523.

Buffenmeyer, C. L., RycheK, R. R. \& Yee, R. B. (1976). Bacteriocin (klebocin) sensitivity typing of Klebsiella. Journal of Clinical Microbiology 4, 239244.

CHAK, K.-F. \& JAMES, R. (1984). Localization and characterization of a gene on the ColE3-CA38 plasmid that confers immunity to colicin E8. Journal of General Microbiology 130, 701-710.

CHAK, K.-F. \& JAMES, R. (1985). Analysis of the promoters for the two immunity genes present in the ColE3-CA38 plasmid using two new promoter probe vectors. Nucleic Acids Research 13, 2519-2531.

CHAK, K.-F. \& JAMES, R. (1986). Characterization of the ColE9-J plasmid and analysis of its genetic organization. Journal of General Microbiology 132, 61-71.

COOPER, P. C. \& JAMES, R. (1985). Three immunity types of klebicins which use the cloacin DF13 receptor of Klebsiella pneumoniae. Journal of General Microbiology 131, 2313-2318.

Cross, A., Allen, J. R., Burke, J., Ducel, G., Harris, A., John, J., Johnson, D., LEw, M.,
Macmillan, B., Meers, P., Skalove, R., Wenzel, R. \& Tenney, J. (1983). Nosocomial infections due to Pseudomonas aeruginosa: review of recent trends. Reviews of Infectious Diseases 5, Supplement 5, S837S845.

Cryz, S. J., Mortimer, P. M., Mansfield, V. \& GERMANIER, R. (1986). Seroepidemiology of Klebsiella bacteremic isolates and implications for vaccine development. Journal of Clinical Microbiology 23, 687-690.

Edmondson, A. S. \& Cooke, E. M. (1979). The development and assessment of a bacteriocin typing method for Klebsiella. Journal of Hygiene 82, 207223.

Gaston, M. A., Ayling-Smith, B. \& Pitt, T. Y. (1987). New bacteriophage typing scheme for subdivision of the frequent capsular serotypes of Klebsiella spp. Journal of Clinical Microbiology 25, 1228-1232.

GUYER, M. S. (1978). The $\gamma \delta$ sequence of $F$ is an insertion sequence. Journal of Molecular Biology 126, 347-365.

HALL, F. A. (1971). Bacteriocine typing of Klebsiella spp. Journal of Clinical Pathology 24, 712-716.

Heddell, G. W. \& Mitchell, A. B. (1978). Evaluation and application of an improved bacteriocin typing method for Klebsiella aerogenes. Journal of Clinical Pathology 31, 16-21.

Herschman, H. R. \& Helinski, D. R. (1967). Comparative study of the events associated with 
colicin induction. Journal of Bacteriology 94, 691699.

ISRAIL, A. M. (1981). The significance of bacteriocin typing of Klebsiella strains. Zentralblatt für Bakteriologie und Hygiene (Abteilung I, Originale A) 250, 6371.

JAMES, R., SchNeIder, J. \& COOPER, P. C. (1987). Characterization of three group A klebicin plasmids : localization of their $\mathrm{E}$ colicin immunity genes. Journal of General Microbiology 133, 2253-2262.

LAEMMLI, U. K. (1970). Cleavage of structural proteins during the assembly of the head of bacteriophage T4. Nature, London 227, 680-685.

Males, B. M. \& Stocker, B. A. D. (1982). Colicins E4, E5, E6 and A and properties of $b t u B^{+}$colicinogenic transconjugants. Journal of General Microbiology 128 , 95-106.

Maniatis, T., Fritsch, E. F. \& SambrooK, J. (1982). Molecular Cloning: a Laboratory Manual. Cold Spring Harbor, NY: Cold Spring Harbor Laboratory.

MILLER, J. (1972). Experiments in Molecular Genetics. Cold Spring Harbor, NY: Cold Spring Harbor Laboratory.

Mock, M., Mryada, C. G. \& Gunsalus, R. P. (1983). Nucleotide sequence for the catalytic domain of colicin E3 and its immunity protein. Evidence for a third gene overlapping colicin. Nucleic Acids Research 11, 3547-3557.

ØRSKOV, I. \& ØRSKOV, F. (1984). Serotyping of Klebsiella. Methods in Microbiology 14, 143-164.
Ozeki, H., Stocker, B. A. D. \& SMith, S. M. (1962). Transmission of colicinogeny between strains of Salmonella typhimurium grown together. Journal of General Microbiology 28, 671-687.

Pugsley, A. P. \& OudegA, B. (1987). Methods for studying colicins and their plasmids. In Plasmids: $\boldsymbol{A}$ Practical Approach. Edited by K. G. Hardy. Oxford: IRL Press.

Pugsley, A. P. \& Schwartz, M. (1983). A genetic approach to the study of mitomycin induced lysis of Escherichia coli $\mathrm{K} 12$ strains which produce colicin E2. Molecular and General Genetics 190, 366-372.

Shafferman, A., Flashner, Y. \& Cohen, S. (1979). ColE1 DNA sequences interacting in cis, essential for mitomycin C induced lethality. Molecular and General Genetics 176, 139-146.

SLOPEK, S. \& MARESZ-BABCZYSZYN, J. (1967). A working scheme for typing Klebsiella bacilli by means of pneumocins. Archivum immunologiae et therapie experimentalis 15, 525-529.

SuIT, J. L., FAN, M.-L. J., SABIK, J. F., LABARRE, R. \& LURIA, S. E. (1983). Alternative forms of lethality in mitomycin C-induced bacteria carrying ColEl plasmids. Proceedings of the National Academy of Sciences of the United States of America 80, 579-583.

VIEIRA, J. \& MEssing, J. (1982). The pUC plasmids, an M13mp7 derived system for insertion mutagenesis and sequencing with synthetic universal primers. Gene 19, 259-268. 